\title{
ANTIQUITY
}

Potential collapse of the bank-only 2 years old-was a problem which had to be faced in cutting the first section in 1962. To avoid undue weight on the bank a gantry of scaffolding was built across it. (This was so useful in excavation that it was also used in 1964.) In the event the bank did stand up satisfactorily (PL. XXvirib shows the 1964 section). In the two sections the distortion of the polythene tubes (see FIG. I) clearly showed the compaction of the turf stack and also that there was some lateral movement in the bank. The layers of the bank were easily recognized by the coloured chippings which had been sprinkled at each interface. Calculation confirmed that very little compaction had taken place in the chalk rubble layers.

Various materials of potential archaeological interest had been buried under the turf stack and also in the chalk rubble of the bank. Specialist reports are still incomplete even for materials recovered in 1962 , but a few preliminary results may be mentioned here.

Billets of oak and hazel, both charred and uncharred, were found to be under vigorous attack by fungi. By 1964 the oak billets averaged only about two-thirds and hazel just over threequarters of their original weight. So far there is no indication that charring has any preservative effect.

After 2 years' burial, textiles of wool and cotton had deteriorated badly under the turf stack; in fact, some cotton samples had disappeared completely. Similar samples in the chalk milieu were less damaged, but here too vigorous microbiological activity was shown by discoloration and fibre damage. In both wool and cotton it seemed that dyeing had had some preservative effect on the fibres.

\section{Standing Field Stones in Kansas}

Travelling recently by car through the limestone country on Highway 36 east of Cawker City in the Solomon River valley of north central Kansas, in the United States, I observed that, for several miles, instead of there being wooden or metal posts supporting the strands of wire forming the fences around the field crops, these were supported by stone posts. These varied
Pottery fragments showed, somewhat surprisingly, no physical or chemical change after 2 years, but cremated bone was found to have become harder and less friable.

Before the construction of the bank, spores of Lycopodium had been dusted over the ground to simulate pollen rain and these were traced after 2 years by pollen analysis. Under the turf stack they remained confined to the turf on which they had been deposited, but elsewhere they had moved both downwards and upwards, apparently through the action of earthworms.

The vigorous biological activity, even in the core of the bank, is a rather unexpected result of the experiment. Destruction of the buried materials by fungi and bacteria indicates adequate aeration, as does the earthworm activity, which by 1964 had reached the turf stack. Worms have clearly been active throughout the bulk of the bank, and casts were found at all levels in interstices in the chalk rubble.

A final point is of particular archaeological significance. Pottery markers which had been placed in the ground outside the ditch edge were found on the floor of the ditch on the centre line, having fallen in with overhanging turves. In such a situation artifacts would normally have been taken to be contemporaneous with the ditch; but these markers could represent artifacts of much earlier date than the ditch itself. It follows from the pattern of scree formation in the ditch that artifacts lying in the angle near the wall are much more likely to be contemporary with the ditch than those lying on the centre line--even if these are actually on the cut floor of the ditch.

G. W. DIMBLEBY

\section{PLATE XXVII}

in above-ground length from about 2 to $6 \mathrm{ft}$. in height and were very approximately $\mathrm{I}$ to $2 \mathrm{ft}$. along the sides. Several such stone fence posts are illustrated here; the manner by which the wire was attached to the posts is indicated-a retaining wire around each post at each level of the horizontal field wire (PL. XXVII). It will be noted how deeply the retaining wire has cut 


\section{PLATE XXVII}
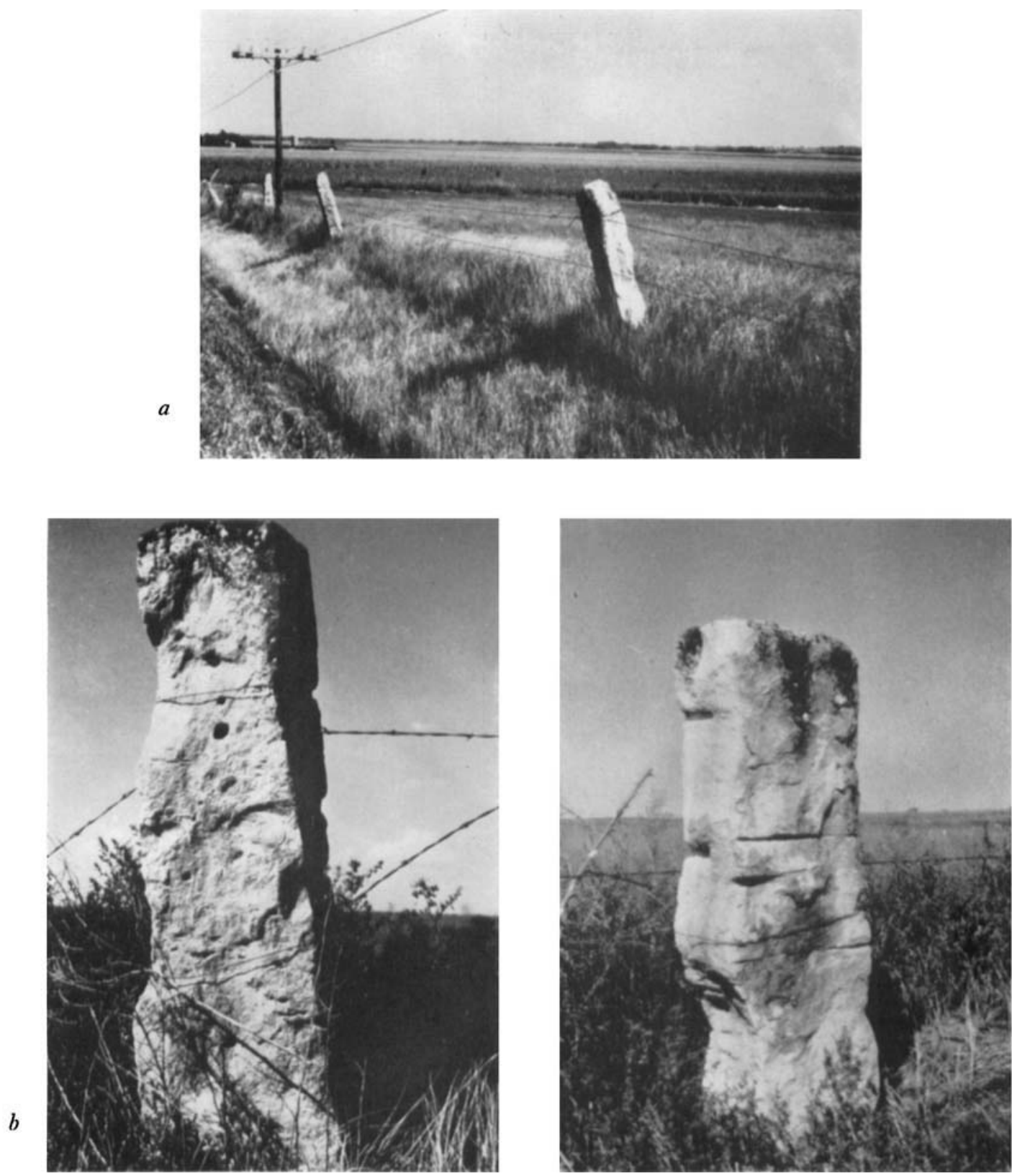

STANDING FIELD STONES IN KANSAS

(a) Line of stone fence posts bordering a field, with supporting wire sirands. (b) Close-up of a single post with retaining wire around it; note impressions of large pelecypod molluscs in the block of limestone. (c) Deep grooves caused by wire under tension; top and middle left: drill-marks made during quarrying.

See pp. I 36-7] 


\section{NOTES AND NEWS}

into some of the stones (cuts should not be confused with the drill-marks during quarrying which are also visible), and this suggests the effects either of high winds over a long period or else the added tension existing when one of the line of stones starts to lean over, or actually falls, with the horizontal wire still attached.

These stones were, of course, entirely modern, and indeed in the town of Portis, Kansas, I observed that there was a company named 'Dierks Fence Stones' which evidently specializes in supplying these limestone posts to the local farmers. Perhaps this is merely a modern touch, but upon coming across these fence stones (and when photographing them) I had the feeling very strongly that there must be an archaeological analogy in what I was seeing. Apart from his use of standing stones for religious purposes, did not ancient man in Europe delineate or fence-off plots of agricultural ground from domestic and wild animals and from neighbours other than by solid wooden barriers or stone walls, i.e. by fences? And if so must it be assumed that he always used wooden posts for the purpose? Here in Kansas, in country where workable limestone outcrops on the surface, was a living example of standing stones being used for fencing, and it suggested that unexplained groups, or intermittent or broken series, of standing stones in western Europe should be surveyed from the premise that they might have formed the boundary of some plot of agricultural activity-and that where modern man naturally uses wire, ancient man used a vegetable fibre or cord as the rope strands connecting stone field posts. If so, perhaps the marks of their abrasion against the stones under tension might sometimes be detectable in a somewhat less exaggerated form than that produced by the retaining wires in the Kansas fences.

M. T. MYRES

\section{Town Defences in Roman Britain}

We have received the following comment from Professor S. S. Frere upon Dr Michael G. farrett's note (ANTIQUITY, 1965, 57), 'Town Defences in Roman Britain'. We invited Drfarrett to make a brief rejoinder, printed on $p .139$.

Dr Jarrett's attempt to throw doubt on the duality of Romano-British town defences in the March number of ANTIQUITY is plausible, but on closer examination superficial. It shows no sign of being based on that careful consideration of all the evidence which an authoritative treatment of the subject demands. His method is first to lay down a pattern of what he thinks ought to have happened on the assumption that walls and banks were part of one programme: and the rest of his argument follows from these assumptions. But this assumed pattern is quite arbitrary and theoretical, nor does it agree with the facts that are known. 'A composite earthwork consisting of an earth or turf bank behind a stone wall will normally reveal two structural phases, even if the two elements form a single plan. ... Common sense indicates that the bank will normally be structurally earlier than the wall. ...'
Why not look at some published sections? A study of these shows that town walls in Britain fall into three classes: (i) Those with no bank. These are few in number and late in date (Great Chesterford, Catterick). (ii) Those with a bank to rear which has been cut away to insert the wall. (iii) Those with a bank to rear which has not been cut away but has been piled up behind the wall as it rises, sealing the offsets and often containing mortar-spreads at intervals which show that progressive levels of the bank were used instead of scaffolding. To this class belong Verulamium, Canterbury, London, Leicester, Caistor by Norwich, Great Casterton, Aldborough, Ancaster and Water Newton. This list, which could probably be extended, is sufficient to dispose of $\mathrm{Dr}$ Jarrett's airy generalizations about which was 'normal' or 'common sense.'

What of group (ii)? Here a different procedure was adopted. A bank which was structurally earlier had its front cut away in order to insert a wall. Why? The great weight of a town wall could not be perched on the very edge of a ditch without danger of collapse: a berm was 